\title{
Human Herpesvirus 8-Positive Neoplastic Cells Present
}

National Cancer Institute

\section{Source}

National Cancer Institute. Human Herpesvirus 8-Positive Neoplastic Cells Present. NCI

Thesaurus. Code C73941.

An indication that human herpesvirus 8 has been detected in a sample of neoplastic cells. 